УдК 32.019.5:94(100)"1914/1918"(093.2)

159.923:355.082(497)”1939/1945“(093.2)

Прегледни научни рад

Примљен: 19. 5. 2016.

Прихваћен: 27. 6. 2016.

Mile BJELAJAC

Institute for Recent History of Serbia mile.bjelajac@gmail.com

\title{
The Impact of the WWI on the Officers' Mind-set in the Balkan Affairs: Interwar, WW II and after (Humanitarian Aspect) ${ }^{1}$
}

\begin{abstract}
Author of this survey article tries to indicate multiply legacies of the First World War on the army officers' mind-set in the interwar years and especially during the Second World War at the Balkan war theatre. The experience of Austro-Hungarian officers on the South and Eastern Front 1914-1918 no doubt influenced the once middle ranked or junior officers at the same theatres of war in the period after 1941. It was not only combat experience and frustration but attitudes stirred up by propaganda as well.
\end{abstract}

Key words: war crimes, Balkan, Wermacht, Austro-Hungarian officers, ISC, Salonika Front, Serbia, Uprising in Toplica, Chetniks

Human nature in politics has been in the historians' scope for the long time now. Mentalities and ego-history have been the subjects of essays on political culture or biographies. ${ }^{2}$ The specific "human touch" in diplomacy, warfare, politics even culture in a broader sense has sometimes been left out so it is worthy to put emphasis on the following remarks by Namier:

1 This article has been written within framework of the scholarly project Tradition - Historical Heritage and National Identity in Serbia in $20^{\text {th }}$ Century (No. 47019), funded by the Ministry of Education, Science and Technological Development of the Republic of Serbia. This article is mainly based on the paper presented at èStoria 2014 - X International History Festival, Gorizia, May 22-25 2014.

2 L. B. Namier, "History and Political Culture", The Varieties of History from Voltaire to the Present, ed. Fritz Stern, (New York, 1973), 371-386; Robert J. Young, "Formation and Foreign Policy: Biography and Ego-Histoire", French History Oxford Journals 24 (2), (2010, April), 144-163. 
"The subject matter of history is human affairs, men in action, things which have happened and how they happened; concrete events fixed in time and space, and their grounding in the thoughts and feelings of men - not things universal and generalized; events as complex and diversified as the man who wrought them, those rational beings whose knowledge is seldom sufficient, whose ideas are but distantly related to reality and who are never moved by reason alone (...) complex social setting adds enormously to the mass of human actions determined neither by vital instinct nor by reason but by a routine inherent in that setting. Thus the past is on top of us and with us all the time (...) by knowing how these things have come to be, which helps to understand their nature, character, and their correlation, or lack of correlation, to the present realities of life."

The social setting could be imposed by the attitude of the teachers upon the youngsters as well as by curriculum. Mass feelings could also be produced by traumatic and frustrated life experiences. This very fact also pertains to political leaders. Examples of prominent leaders, like the French ones who experienced humiliation or were even refugees in their young age in 1870/71, the Serbian ones after Annexation of Bosnia and Herzegovina in 1908, or the German (Austrian) ones after the lost war in 1918, demonstrates the importance of addressing this issue. How they would remember a traumatic series of events is what shaped and pushed them to adopt stands in the new circumstances.

Marking 100 years since the start of World War One attracts not only academic circles but the broader public as well. In spite of frequently exposed desires "to leave the past in the past", we are still observing how even the distant past has shaped mentalities ever since. But as usual, it is not only the past itself but its (ab)use for a political purpose. Sometimes it is not clear whether we are faced with a standard narrative which stems from political mentality as well as from the national identities or with intentional distortions.

The long 19 century that had started with the French revolution and ended in the fall of 1918, actually did not cease to exist in many ways. The mental maps, ideas, even political movements that had been developed in the nineteenth century would continue to shape the post-war world along impacts of the Great War itself. The very fact is that the war struck heavily upon sentiments and mind-sets but one should always bear in mind the broader legacy from the pre-war years. ${ }^{4}$

3 Namier, 372-373.

4 Milorad Ekmečić, "Politička biografija generacije (mesto Prvog svetskog rata u istoriji)", Ogledi iz istorije, (Beograd, 2002), 163-190, 163; Thomas J. Knock, To End all Wars, Woodrow Wilson and the Quest for a New World Order, (New York, 1992), 13, 14; François Furet, Le passé d'une illusion, Essai sur lidée communiste en XXe siècle, (Paris, 1995), 269. 
How far it could go one can see even in 1990s. In his bitter assessment of the Yugoslav issue the French president told his Greek colleague Andreas Papandreou:

"Everything was a sequence of errors: the German action, American ignorance, Italian hesitation provoked by the attitude of the Holly See. Actually, Germany who saw itself as the legitimate successor of the Austro-Hungarian Empire, has adopted all of the rage the Austrians felt against the Serbs." ${ }^{5}$

Generation 1880-1890 that encompassed army officers also had a prominent role not only throughout the wartime but also during the interwar years and later on in World War Two. Some of them would still have a prominent role in 1950s. In the case of Yugoslavia, we can list some prominent personalities like: deputy to the prime minister and famous leader of the Croat Peasant Party (HSS), Dr Vlatko Maček who served as a reserve officer in $42^{\text {nd }}$ (Croatian) Division that fought in Serbia 1914 or Prime Minister Dr Ivan Šubašić (a Croat) who also served as a reserve officer and later on as a Yugoslav volunteer. The most prominent one was Joseph Broz Tito, Yugoslav Marshall then an NCO who fought in Serbia 1914 in the same $25^{\text {th }}$ Regiment (Zagreb). In addition, we can list the lawyer Dr Mirko Puk and novelist Mile Budak future ministers in Pavelićs Croat Government (1941-1945), and notorious war criminals. They also took a part in the war campaign against Serbia as reserve officers in 1914. Budak was captured and he experienced later the Serbian withdrawal through the Albanian mountains to the Adriatic littoral.

An excellent book by Ben Shepherd on terror in the Balkans in WW II, alongside with other accounts, ${ }^{6}$ inspired me to evoke some specific aspects of the WW I legacy that had impact on WW II and even after.

$5 \quad$ Hubert Védrine, Les Mondes de François Mitterand, (Paris: Fayar, 1996), 625.

6 Ben Shepherd, Terror in the Balkans / German Armies and Partisan Warfare, (London: Harvard University Press, Cambridge), 2012; Walter Manoschek, "Serbien ist Judenfrei", Militärische Besatzungspolitik und Judenvernichtung in Serbien 1941/42, R. Oldenburg Verlag, (München, 1993), (In Serbian: Holokaust u Srbiji. Vojna okupaciona politika i uništavanje Jevreja 1941-1942, (Beograd, 2007)); Jonathan E. Gumz, The Resurrection and Collapse of Empire in Habsburg Serbia, 1914-1918, (Cambridge University Press, 2009); Alan Kramer, Dynamic of Destruction. Culture and Mass Killing in the First World War, (Oxford University Press, 2007); Istvan Deak, Beyond Nationalism. A Social and Political History of the Habsburg Officer Corps 1848-1918, (Oxford University Press, NY/Oxford, 1990); Vasa Kazimirović, NDH u svetlu nemačkih dokumenata i dnevika Gleza fon Horstenaua 1941/1944, (Beograd, 1987); Tko je tko u NDH, Hrvatska 1941.-1945., (Zagreb: Minerva, 1997); Dr Đorđe Lopičić, Nemački ratni zločini 1941-1945. Presude jugoslovenskih vojnih sudova, (Beograd, 2009); John Paul Newman, The Croatian God Mars: The Impact of the War on the Male Wartime Generation in Croatia, (PhD thesis, Southampton University, 2008). 
Shepard, as well as Walter Manoschek, and some others noticed that the majority of the high Wehrmacht officers engaged in the Balkan campaign 1941/1945 were of Austrian or Austro-Hungarian descent. According to Manoschek, under the command of General Frantz Boehme, commanding officer in occupied Serbia, Austrians alone comprised one third of the occupation forces in 1941. Some of them had direct experience in the Balkans or Eastern front during the Great War. Not to mention the Hungarians who were also engaged. Commanding Generalsat on the Yugoslav soil during wartime like Alexander Löhr, Lothar Rendulic, Frantz Boehme, Paul Bader, Edmund Glaise von Horstenau, Maximillian de Angelis, Julius Ringel, Walter Hinghofer, Paul Hofman, Adalbert Lontschar, Alois Vindis, Johan Mikl were former k.u.k. officers. Radomir Luza calculated that more than 200 Wehrmacht

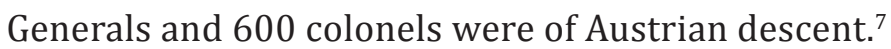

On the other hand, many top ranking officers in the Independent State of Croatia (1941-1945) had wartime experience fighting in Serbia, Macedonia, Bosnia and Montenegro (1914-1918). Some 81 Generals and colonels, former k.u.k. officers have been listed in Who is Who in Independent State of Croatia. ${ }^{8}$

The troops under command of the former k.u.k. officers committed atrocities and war crimes as early as in the summer of 1914. The atrocities and maltreatment were also directed against the Serbian population in Bosnia and Herzegovina, ${ }^{9}$ as well as against civilians during the occupation of Serbia and Montenegro. However, what some of them have done in WW II was not for the first time in their lives. ${ }^{10}$

What those in Wehrmacht or in the Croat army had in common was a ruthless attitude not only against the armed insurgents but the ci-

7 Kazimirović, NDH u svetlu nemačkih dokumenata, 8, nap. 4 (After. Radomir Luza, Östereich und die grossedeutsche Idee, 263).

8 Tko je tko u NDH.

9 Đorđe Mikić, Austrougarska ratna politiku u Bosni i Hercegovini 1914-1918, (Banja Luka, 2011). See: „Rat sa podanicima“, Chapter I.

10 Vladimir Ćorović, Crna knjiga: Patnje Srba Bosne i Hercegovine za vreme Svetskog Rata 1914-1918, (Beograd, 1920; Beograd - Novi Sad, 2015); Rudolf Archibald Reiss, Comment Les Austro-Hongrois ont fait la guerre en Serbie. Observations direct d'un neutre, (Paris, 1915); Dr A. Van Tienhoven, Avec les Serbes en Serbie et en Albanie 1914-1916. Journal de Guerre d'un Chirurgien, (Paris, 1918) (In Serbian: Sa Srbima u Srbiji i Albaniji 1914-1916. Ratni dnevnik jednog hirurga, Beograd - Novi Sad: Prometej-RTS, 2015); Edmond Paris, Genocide in Satellite Croatia 1941-1945. A Record of Racial and Religious Persecutions and Massacres, (Chicago, 1962); L. Hory, M. Broszat, Der kroatische Ustascha-Staat 1941-1945, (Stuttgart, 1964); Gert Fricke, Kroatien 1941-1945. Der "Unabhängige Staat" in der Sich des Deutschen Bevollmachtgten Generals in Agram Glaise v. Horstenau, (Freiburg, 1972). 
vilian population as well. Why? What drove them to adopt such a pattern? This practice brought them ultimately before the Nuremberg court or before the courts in former Yugoslavia.

It has already been stressed in several recent historical accounts, that their wartime experience 1914-1918 and frustrations caused by losing the war, by losing their country and, if you like, their identity, had great impact on their attitudes in the Second World War. On the other hand, they were influenced by experience in the new successor states that was not satisfactory (at least for some of them). However, some additional questions deserve to be addressed too. In the first place how Austria-Hungary over the long period of time had prepared the minds of its Officer Corps and public opinion for the future war campaign against Serbia. One must also take into account how Germany had developed anti-Slavic bias on her part. ${ }^{11}$

Nineteen century Europe among other ideas was a cradle of racial theories sometimes mixed with social Darwinism. ${ }^{12}$ The existence of anti-Slavism in the pre-war German Officer Corps was evident. It was directed against the "East" as the old echo of Russophobia, common to the West in general. The attitude was fostered in reaction to the pan Slavic ideology. There was a notion of a German moral mission to civilize its backward, eastern neighbours. In the words of General Helmut Moltke Jr. it would be "racial struggle between Germanic and Slavic races". In his letters to General Conrad von Hetzendorf he explained that it is "the duty of all states that carry the standard of Germanic culture to prepare themselves for this." ${ }^{13}$ On the other hand, in spite of the multi ethnicity of the Habsburg Officer Corps, there was an obvious anti-Serbian attitude and anti-Slavism within Monarchy. ${ }^{14}$ General Conrad, as a junior officer took part in fighting Slavic irregulars in occupied Bosnia and Herzegovina in the period 1878-1882. In his view they (the Slavs) were cruel, bestial and bloodlust. He and his soul mates like General and military

11 Milan Ristović, Crni Petar i balkanski razbojnici, Balkan i Srbija u nemačkim satiričnim časopisima (1903-1918), (Beograd, 2011). See also: Milan Ristović, Black Peter and Balkan Brigands. The Balkans and Serbia in German Satirical Journals 1903-1918, (Beograd, 2003).

12 Georg L. Mosse, Towards the Final Solution. A History of European Racism, (New York, 1978) (In German translation: Die Geschichte des Rassismus in Europa; na srpskom: Džordž L. Mos, Istorija rasizma u Evropi, Beograd: Službeni glasnik, 2005).

13 Annika Mombauer, Helmut von Moltke and Origins of the First World War, (Cambridge University Press, 2001), 152.

14 Istvan Deak, Beyond Nationalism. A Social and Political History of the Habsburg Officer Corps 1848-1918, (NY/Oxford: Oxford University Press, 1990); See also: Gunther Rothenburg, The Army of Francis Joseph, (Purdue University Press, 1998). 
Governor of Bosnia and Herzegovina Oskar Potiorek, would prepare to deal with local Serbs in Eastern Bosnia and Herzegovina in case of war. The Balkan Wars that stirred up sentiments among South Slavs in the Monarchy provoked concern within ranks. War was seen as an option for salvation against the threats. "Unsurprisingly, those years saw Austrian journalists take an increasingly bellicose line against Serbia. After the Annexation of Bosnia in 1908 some officers saw apparently an imminent battle between superior Germans and inferior Slavs." ${ }^{15}$ According to $\mathrm{Au}-$ strian Chief of the General Staff, one can talk of superior and inferior states not races. But for his subalterns the idea of an existence of superior nationality or religion, or civilisation was already there. One fact must not be overlooked in the Balkans. A certain fraction among k.u.k. officers of Croat descent was at the time affiliated with the ideas of Pure Party of the Right (Frankist). The Party was loyal to the Habsburgs but highly anti-Serb, anti-Semitic and anti-Yugoslav oriented. They opposed the policy of the ruling Croat-Serbian Coalition. ${ }^{16}$ The party in question used to demonize and "dehumanize" Serbs as the "breed of impure blood", "false brothers" etc., well before July 1914. After the assassination in Sarajevo they stirred up anti-Serb emotions in public and among the ranks. Josip Broz Tito, NCO at the time in 25th Infantry Regiment (Zagreb), later recalled that his battalion commander Slavko Štancer and his platoon leader Ivan Tomašević, future generals in ISC (Independent State of Croatia) did not hide their hate against Serbs. Tito declined to pardon them after the Military Court for War Crimes had sentenced them to death in 1945. ${ }^{17}$ His regimental commander at the time, and also General of ISC, Ante Matasić died during the war (1942). Prominent staff officer Lt. Colonel Slavko Kvaternik, who was the son in law of the Francist's Party leader Joseph Frank, had even enrolled in former Yugoslav Army, but soon left the ranks on his request. He became the first commander in chief of ISC Army as newly promulgated marshal. He had escaped to Austria in 1945 but the Americans extradited him to Yugoslavia and he was put on trial for war crimes and executed.

The historians concluded that WW I not only had a personal impact on individuals but was also used as a symbol for justification of the

15 Ben Shepherd, Terror in the Balkans / German Armies and Partisan Warfare, (Cambridge, London: Harvard University Press, 2012), 20-21.

16 Local Parliament of Croatia and Slavonia (Zagreb). See for more: Bogdan Krizman, Hrvatska u Prvom svjetskom ratu, Hrvatsko-srpski politički odnosi, (Zagreb, 1989).

17 Vladimir Dedijer, Josip Broz Tito. Prilozi za biografiju, (Beograd: Kultura, 1953), 62; Tko je tko u NDH, 226-227, 260, 389-390, 399, 458; Nikica Barić, Ustroj kopnene vojske domobranstva Nezavisne države Hrvatske 1941.-1945., (Zagreb, 2003); Ivan Košutić, Hrvatsko domobranstvo u Drugom svjetskom ratu, (Zagreb, 1992). 
most severe measures that were applied in the Balkans later on. The reprisals that were carried out by the troops were exceptional, even by Nazi standards, in the scale of indiscriminate butchery. The historian Sam Shepard finds that the words of commanding General Franz Boehme, the Wehrmacht's Plenipotentiary in Serbia, demonstrate this very clearly:

"Your objective is to be achieved in a land where, in 1914, streams of German blood flowed because of the treachery of the Serbs, men and women. You are the avengers of those dead. A deterring example must be established for all of Serbia, one that will have the heaviest impact on the entire population. Anyone who carries out his duty in a lenient manner will be called to account, regardless of rank or position, and tried by a military court." 18

It was almost similar to the order issued by commanding General of IX Army Corps Lothar Horstein, back on 14 August 1914, before his troops entered Serbia: "War brings us into one hostile country inhabited by people fanatically hostile towards us; a country where perfidious murder, as the catastrophe in Sarajevo demonstrates, (...) has been celebrated as heroism. Any human and merciful approach towards such people is not welcomed; on contrary it could be harmful (...) for security of our own troops. Therefore, I am ordering that the most harsh, strict and full of hatred attitude should be adopted in that regards. (...) Anyone who exposes mercy would be severely punished." ${ }^{19}$ The same order prescribed the rules for taking hostages and their immediate execution under any excuse. The notorious crime against civilians that occurred in the Serbian town Šabac, on 17 August 1914, was a direct result of the above mentioned order. The hostages that were held in the Orthodox Church, over 80 in total, were slathered with bayonets. In nearby Prnjavor the Austro-Hungarian army took 109 civilians as hostages and executed them all in Lesnica on 14 August. $^{20}$

In Sarajevo, General Michael Ludwig von Appel, commander of XV Army Corps, issued an order on August 10, 1914 that envisaged violation of humanitarian war law:

"We not only have to win here but also shatter and destroy the

18 Shepherd, Terror in the Balkans, 2.

19 Arhiv Srbije, MID-PO, F-XVI/1914, 16, Dos. IV.

20 Anton Holzer, „Schüsse in Sabac, Die Massaker an der Zivilbevölkerung 1914“, Der Grosse Krieg. Der Erste Weltkriege im Spigel der serbischen Literatur und Presse, Gordana Ilic Markovic (Hg.), Promedia, (Wien, 2014), 77-83; Anton Holzer, Das Lächeln der Henker. Der unbekannte Krieg gegen die Zivibevölkerung 1914-1918, (Darmstadt: Primus-Verlag, WBG, 2014) (In Serbian: Anton Holcer, Dželatov smešak. Nepoznati rat protiv civilnog stanovništva 1914-1918, (Novi Sad - Beograd, 2015), 219-233). 
Serbo-Montenegrin army - this is the carrier of Russian ideas and propaganda. Above all we must thoroughly wean them of their megalomania and arrogance (...) I have forbidden my officers under pain of punishment with loss of honour to treat Serbian officers on an equal footing (...) If they are captured (...) they are to be treated like common soldiers $(\ldots)^{\prime 21}$

General Rudolf von Braun (1861-1920), commander of Trebinje fortified zone (Eastern Herzegovina) acted accordingly to the instructions of his superior Generals Oskar von Potiorek and Appel. He rounded up hostages and executed 77 male civilians and two females in August and September 1914. Among others the Austrians hanged the local priest Vidak Parezanin. He never questioned acts of violence upon Serbian dwellers committed by local "Schutzcorps" militia, basically of Muslim origin. Everything went according to Local Government instruction for the treatment of the Serbian population within the Monarchy issued on 28 August $1914 .{ }^{22}$

One can notice that General Boehme was not the only one who was driven by his previous war experience when he acted in new circumstances (1941). The very same path could be observed in the behaviour of his predecessors like Generals Conrad von Hetzendorfor Max von Gallwitz commander of the Army Corps in Belgium in August 1914. Both had experience with the irregulars $(1870,1882)$ and both had instructed their troops how to behave accordingly. General von Gallwitz issued his famous order: "An example has to be made; all captured men are to be shot". However the practice was also extended to women and children. The cities of Dinant, Louven or Andenne became known for mass executions of civilians. ${ }^{23}$

However, the atrocities committed during the first weeks of the 1914 campaign in Serbia did not help at all. All three Austro-Hungarian attempts to vanquish Serbia - in August, September and November - were humiliatingly routed by the Serbian army. Almost 60,000 Austrian-Hungarian officers and soldiers became POW in Serbia. This fact left an unforgettable impression and lasting frustration. After the Serbian disaster in late 1915, the Serbs left their territory but also took tens of thousands Austrian and German POW with them through the Albanian and Montenegrin icy mountains. The deadly march could only stir up Austrian hard feelings. Furthermore, occupying forces, Austrian and Bulgarian,

21 Shepherd, op. cit., 29.

22 Vladimir J. Popović, Patnje i žrtve Srba Sreza Trebinjskog, (Trebinje, 1929; reprint: Trebinje, 1996), 9, 18; M. Ekmečić, Dugo kretanje između klanja i oranja. Istorija Srba u Novom veku (1492-1992), (Beograd, 2007), 342-344.

23 Alan Kramer, Dynamic of Destruction. Culture and Mass Killing in the First World War, (Oxford University Press, 2007), 14-19. 
had to deal with insurgents and popular uprising in 1917. Ultimately, it was on the Balkan battleground where the Central Powers lost their final battle. As Ben Shepard put it "In September 1918, finally, the Serbian army would be instrumental in breaking the Macedonian Front - the key military event that heralded the Austro-Hungarian Empire`s complete collapse." ${ }^{24}$ All this, from the assassination of Franz Ferdinand, the military humiliation in 1914, corrosive effect of the Serbian army on Austrian army moral, and finally direct role in the empire's disintegration enabled "Wehrmacht commanders to stir Austrian hatred and resentment against the Serbs during World War II." 25

The members of the Habsburg Officer Corps and men, German ones as well, have experienced the East, the Slav people, and Russian prisoners' camps, civil and the Bolshevik revolutions. Some experienced the counter-insurgents operations or the pacification of certain occupied territories. The above mentioned officers had also been exposed to the permanent state and ideological propaganda.

The generation 1880-1890 would carry on its legacy that encompassed not only the above listed experiences but much more. In the first place, it was "home front" (or Innere Front). ${ }^{26}$ In many aspects the rule of law had deteriorated. Many became deserters. The values that active Officer Corps stood for were abandoned daily as well as its beloved discipline and order. They knew how families suffered at home, as well as their handicapped brothers in arms. In 1918 many officers turned to the new national liberation course, even some firm loyalists.

The fate of the former k.u.k. officers in successor states, inclusive those in the newly created Kingdom of SCS, have already been discussed in historiography. There are some differences in approach to the topic as well as in the final conclusions. ${ }^{27}$

\section{Shepherd, op. cit., 36.}

25 Ibid.

26 R. G. Plascha, H. Haselsteiner, A. Suppan, Innere Front, Militärassistenz, Widerstand und Umsturz in der Donaumonarchie 1918, (Wien, 1974); Bogdan Krizman, Raspad Austro-Ugarske i stvaranje jugoslovenske drzave, (Zagreb, 1977).

27 Ivo Banac, Istvan Deak, R. J. Crampton. - Mile Bjelajac, Vojska Kraljevine SHS 1918-1921, (Beograd, 1988); M. Bjelajac, Jugoslovensko iskustvo sa multietnickom armijom 1918-1991, (Beograd, 1999); M. Bjelajac, "The Military and Yugoslav Unity“, Yugoslavism. Histories of a Failed Idea 1918/1992, ed. Dejan Đokić, (London: Hurst and Co, 2003), 208-221; T. Aralica, V. Aralica, Hrvatski ratnici 2: Razdoblje Kraljevine SHS/Jugoslavije 1918-1941, (Zagreb, 2006); John Paul Newman, The Croatian God Mars: The Impact of the war on the male wartime generation in Croatia, (Ph. D thesis, Southampton University, 2008); Hrvoje Capo, „Broj primljenih časnika bivše austrougarske vojske u vojsku Kraljevstva Srba, Hrvata i Slovenaca“, Časopis za suvremenu povijest, No 3/2008, (Zagreb), 1087-1103. 
Before any discussion on the differences, it has become necessary to lay out the fact that not only new sources or data influence the rewriting of what was Yugoslav history but also recent (different) political perceptions of the Balkans complexity. The Yugoslav crisis has instigated a new reassessment or rather rewriting of many aspects of the 20 century Balkan history. One, who deals with the topic for decades now, could easily recognize different trends. Sometimes the once forgotten, unpleasant but accurate history has emerged from the new historical accounts. Unfortunately seldom do new accounts give legitimacy to the once produced biases or simply political or wartime propaganda. ${ }^{28}$ The discussions on the outbreak of the WWI and its roots could supply examples for both above mentioned approaches. The previous notion could be addressed to the accounts that have recently tackled the issue of the former k.u.k officers.

The creation of the joint army in the Kingdom of SCS was one of the utmost sensitive issues at the time. There were two principal reasons: the army had to represent in the eyes of all citizens their national force, and, on the other hand the army badly needed to remain and to improve its effectiveness since many challenges still faced the country. The army leadership was fully aware of both tasks. Since the country adopted a reconciliation pattern the compromises were inevitable.

Despite some claims in older, pre-1990s accounts, and some newly adopted firm conclusion on former officers' fate, namely that the Habsburg officers were neglected and humiliated in the Yugoslav army, or that "Croats were systematically hounded out of the army", statistics suggests a more profound conclusions. Some 2,590 enrolled into the new officer corps (that is to say 36.76 per cent out of total). In 1924 they formed 4 per cent among all generals and admirals and 9.7 per cent among colonels but 15.8 per cent among lieutenant-colonels and 42.2 per cent among majors. In 1936 they formed 6.6 per cent among generals, 33.35 per cent for colonels, 34.66 per cent for lieutenant- colonels and 47.76 for majors. On the eve of the Second World War 23 per cent of active general corps were formerly officers of the Habsburg army. In the same year, Croats and Slovenes occupied 63.6 per cent of all military attaché posts. The Croat Colonel Vladimir Kalecak was the head of military intelligence 1940/41. The Serbs did dominate the Yugoslav Army, particularly the General Corps. However, there were 12 Montenegrin and 64 former Habsburg officers, as well as two non-Serbs from the former Serbian army (out of 502 in the whole period 1918/41). At the end of the 1930s, Yugoslav officer corps numbered some 10,000. Almost 85 per cent of

28 Mile Bjelajac, Gordana Krivokapić-Jović, Prilozi iz naučne kritike. Srpska istoriografija i svet, (Beograd: INIS, 2011). 
them were young officers who received military education in Yugoslavia. ${ }^{29}$ By the early 1930 s, ranking lists reveals that only 1,000 (out of previous 2,600 ) of the former k.u.k. officers remained on active duty. But at the same time only 1,775 (out of previous 3,500) of the former Serbian wartime officers remained in active service. Whereby paraphrasing the words that fore mention historians use for alleged fate of the "Croat" officers, one can assert that 1,775 former Serbian officers "were hounded out the army", alongside with 1,600 of the former k.u.k. ${ }^{30}$

What we keep inaccurate, is a certain manner of identifying or regarding the whole body of former Hapsburg officers as "Croats". In addition, some historians stick to the group of the Frankist party affiliated officers and take them, their fate or dissatisfaction as a proof for negligence and humiliation of all former k.u.k. officers that had enrolled into joint army.

The National Council of SCS (Government in Zagreb) had run military matters since October 29,1918 . In order to protect the new order Council was eager to eliminate any possible resistance or clandestine activity. So, many of the proven Frankists among officers were removed or denied residence in their homeland. The Council removed some notorious individuals like Slavko Štancer, who was behind the unrest in Zagreb on December 5, 1918. Finally, some weeks after the Yugoslav unification, the National Council in Zagreb announced a long list of retired army personnel. Many were of retirement age even during the war but some were not. Among others, the list contained 31 generals, 74 colonels and 21 colonels from the reserve, inclusive ethnic Croats, Serbs and others. ${ }^{31}$ However, some notorious Frankists remained within the ranks, like Lt. Colonels Slavko Kvaternik and Ivan Perčević. They would quit the ranks later by their personal decisions.

While it would be erroneous to claim that inter-ethnic relations within the army did not pose any problems, especially among two branches of the Officer corps, there is no reliable body of documentary evidence to suggest that the Serbian leadership of the interwar Yugoslav army had chauvinistic or intentionally chauvinistic attitudes towards the army's non-Serbs. The numerous confidential recommendations and orders clearly show that their authors - war ministers, top

29 Bjelajac, "The Military and Yugoslav Unity", 209-210; M. Bjelajac, Generali i admirali Kraljevine Jugoslavije 1918-1941, Studija o vojnoj eliti i biografski leksikon, (Beograd, 2004).

30 Bjelajac, Jugoslovensko iskustvo, 28.

31 Vlada Narodnog Vijeća SHS, Odio za narodnu obranu, Vjesnik naredaba 1918-1919, (Zagreb: Hrvatski državni arhiv, 2008), 155-157. 
army generals and other officers - were fully aware that the harmony within the army was a necessary precondition for high combat morale and loyalty to the state. The military top brass also understood that any dissatisfaction even caused by an non intentional offence would nourish anti-Serb and anti-Yugoslav sentiments both in the army and whole society. ${ }^{32}$

That very trend could be traced to the moment when Yugoslav voluntaries showed up on the Salonika Front coming from Russia. Then Chief of the Staff, General Petar Bojović in his order to all officers emphasized the importance of harmony, respect, tolerance and brotherhood among Serbs and Yugoslavs. He particularly stressed that it was vital that Serbs of the Kingdom of Serbia did not attempt to dominate other Yugoslavs, not just in order to counter the enemy propaganda. The officers and NCO officers were ordered to avoid any actions that could offend pride and dignity of the newcomers or cause suspicion among them. Those who disobeyed were to be put on trial. His successors and ministers acted in the same way. Some of them did not hesitate to punish high Serbian officers with distinguished merits if they acted wrongly or overreacted. Some historians do not want to respect such body of evidence; instead they put more trust in some private letter suitable only to describe personal perception or belief. In addition, they did not compare the position or status of Serbian or Montenegrin officers or their families at the same time. The fact is that they shared, actually the same fate. For example, it took years for the retired Serbian war veterans before 1929, under an unfavourable law, to equalize their status and pensions with those who were retired after 1929. It happened not before 1939. The same goes for all those Slovenes, Croats or Serbs, former k.u.k. officers. No better fate faced the Serbian disabled veteran officers, their widows or war orphans. One cannot neglect fact that it was financial inability that influenced conditions not someone`s malicious will. ${ }^{33}$

The experience in the field suggests that misunderstanding of the real nature of multi-ethnic relationship within the ranks or troops was caused by the hate in political arena of the time. Some protagonist did not have in mind to improve conditions and consequently solidity of the state but to compromise it in the eyes of public (or their respective nation). For that purpose any correct or incorrect claim was welcomed.

The Yugoslav army proved more tolerant and inclusive of the former enemy officers than the Italian army had been after unification in 1870, or Polish after 1918, or West German in the case of reunited Ger-

32 For more, see: M. Bjelajac, Vojska Kraljevine SHS 1918-1921, (Beograd, 1988).

33 M. Bjelajac, Vojska Kraljevine SHS/Jugoslavije 1922-1935, (Beograd, 1994). 
many, to take a more recent example. For example, after the Italian unification, dominant Piedmontisans were the only generals for twenty years.$^{34}$

\section{Dogma of the Salonika Front and Premature Uprising in Toplica 1917}

Not only were the frustrated losers of WWI affected by their experience. The victors' mind-set was also affected. Take for the example the uprising in Toplica against Bulgarian occupiers (1917) or irregular military activities in the Austrian occupied zone since 1916. Once reorganized on the island Corfu and shipped to the Salonika front in the summer 1916, the Serbian Army and its High Command undertook activities to prepare conditions for an uprising in occupied Serbia. The general idea was to instigate uprising simultaneously with a major Allied offensive northwards from the Salonika front. For the purpose they sent by plane Lieutenant Kosta Milovanović Pećanac southwest from Niš, where he was able to contact existing guerrilla groups. His assignment was to contact conscripts, organize them into guerrilla groups and concentrate on sabotaging activities but only when it was "clear that the Bulgarians were withdrawing". ${ }^{35}$ His written orders did not permit him to instigate an immediate uprising. Historian Andrej Mitrović wrote:

"Although his mission was not to enflame the population's urge to resist, or to promote the incipient armed resistance, his arrival in fact had that effect. The news that an officer of the army in exile had arrived, tasked with making preparations for the country's imminent liberation, in itself had the effect of strengthening fighting morale."36

Driven by the local circumstances he found in Serbia, he quickly abandoned his instructions and ordered attacks on supply trains and signed proclamations calling for a people's uprising. As for the consequences, there was a broad national movement and liberation of considerable area. The reaction of the occupiers was severe. Against the forces of approximately 4,000 guerrilla fighters, both Austrians and Bulgarians engaged some 30,000 of whom some 25-26,000 men were engaged in combat. Some 1,800 Serbian fighters were executed or killed in the action. Austro-Hungarian reports of the time (summer of 1917) "mention the figure of 20,000 people killed, which is also the number established by an international commission set up after the war." ${ }^{37}$

\footnotetext{
34 Bjelajac, "The Military and Yugoslav Unity“, 210.

35 A. Mitrović, Serbia's Great War 1914-1918, (London, 2007), 248-249.

36 Ibid.

37 Ibid., 261.
} 
In spite that, some 2,600 fighters escaped into the mountains and woods, along with Milovanović, Vojinović, Vlahović and other guerrillas leaders, the retaliations against the innocent and the suffering of the civilian population, would influence future guerrilla leaders in the Second World War in Serbia. Kosta Milovanović, then an older man and formally leader of an Old Četnik detachment in South Serbia since the April war (1941) was in favour of collaborating with the occupying forces under certain conditions and in order to protect the Serbian population against Albanian maltreatment and persecutions.

The Yugoslav High Command, as was the Serbian in WWI, was in exile in the Middle East since the April war. Their idea was to enlarged the evacuated forces by Yugoslav conscripts or voluntaries from overseas countries, but at the same time it also contemplated guerrilla warfare in the country. When the news of existing resistance in the country reached Cairo, they started preparation to send a mission to Yugoslavia. The instructions were almost similar to the ones given by the Serbian High Command when they sent Kosta Milovanović back in 1916. That is to say, everything had to be done and prepared for the decisive moment when the Allies invaded the Balkans sooner or later.

However, local circumstances once again influenced the behaviour and strategies. Milovanović, as fore mentioned, did not want to provoke the Germans and Bulgarians and give them excuse for retaliation and consequently cause further eradication of the Serbian population. General Milan Nedić, as a president of the so called "Serbian Government" in the German occupied zone would adopt a similar stance. Once a brave Serbian officer, interwar War Minister, Nedić was convinced that powerful Germany would control Europe for years to come. Accordingly, he advised no resistance in any form and adjustment of the local political system to the ruling one in New Europe. The fall of France, doubtful capabilities of the USSR, as well as no United States on horizon, badly shook his self-confidence.

Another prominent figure who established the resistance movement, Colonel Dragoljub Mihailović, also bore in mind the experience of the Toplica uprising and mass retaliation by the occupiers. Therefore, in his first orders he emphasized a need for a clandestine organisation, civil disobedience, and consequently provoking permanent upset and anxiety among the occupiers. In contrast to General Nedić, Mihailović put all his fate in Allied victory and Serbs on their sides. He and his Government in exile, who soon acknowledged him as its representative in the country, shared the same stand - no premature and costly uprising, but preparing organisation, clandestine units and command centres for the moment to come. 
Communist led resistance movement took a different stand upon request from Moscow at the end of June 1941, that is to say, active combat resistance. Needless to mention that such a stand perfectly suited the young people who were eager to fight back the Germans. However, the newly created Mihailović's detachments and their commanders were easily dragged into open combat against German troops and proxy forces. It was just like in 1916 when Kosta Milovanović had landed in South Serbia and felt the mood of the people that led him to disobey his orders.

The initial successes were soon turned into bloody reality. The German commanding General in Serbia and his subalterns imposed a retaliation rate of 1 to 100 , or 1 to 50 for a wounded soldier. Both movements, already engaged in civil strife, were defeated in late 1941. The Partisan leadership moved to Bosnia, and General Mihailović escaped to Montenegro. The German lists of casualties, well below 2,000, did not justify the enormous losses of the other sides.

In the broader context, there is another legacy that the First World War left on the mind-set of top Allied generals and planners. It was the idea of the new Salonika front. As in the old times it was seen as an important and probably decisive one that would relax efforts on the West. The French General Weygand promoted this idea at the beginning. Later on General Gamelin his successor to the post of the Chief of General Staff accepted it. Finally when, the Second World War broke out in September 1939 the idea became more intense since the Western Allies lost hope in the USSR as a potential strategic partner.

At the beginning of 1938, French Prime Minister endorsed an idea coming from the General Staff regarding the establishment of a considerable base and factories for ammunition production in the Middle East in order to supply all Balkan allies more safely and steadily in the case of war. The planners in the West correctly envisaged that under present circumstances there would be no possibilities to supply the Balkan allies via the Western Mediterranean as it was in the previous war. In March 1939, the French government decided to allocate 23 million to establishing a base in Beirut. ${ }^{38}$

The British and the French went on with the plans of building military plants in the Middle East, but obviously they were delayed. In April 1940, they invited future Balkan allies to establish their own factories for their military needs. ${ }^{39}$

General Gamelin had warned his Prime Minister on 12 April and repeatedly on 16 April that French-British intervention would face gre-

38 Service Historique de l'Armée de terre, SHAT, 6N 311 [D 3], SD 5.

39 SHAT 5N 580 [d 9], 16 Avril 1940. 
at problems because of uncertainty in ammunition supply, firstly for the artillery. Again, General Gamelin insisted on proceeding with establishing plants in the safe zone like Middle East, out of air power reach. That would be the best way to supply not only expeditionary forces but the Balkan armies as well.

However, history did not repeat itself as the old warriors expected. France was soon occupied by the German armies. Romania shifted side. Yugoslavia and Greece could resist only for a while in the spring of 1941.

\section{Sources and Literature}

- Service Historique de l'Armée de terre (Paris), SHAT. 5N, 6N.

- Arhiv Srbije. MID-PO, F-XVI/1914.

\section{Literature}

1. Aralica T., V. Aralica, Hrvatski ratnici 2: Razdoblje Kraljevine SHS/ Jugoslavije 1918-1941. Zagreb, 2006.

2. Barić, Nikica. Ustroj kopnene vojske domobranstva Nezavisne države Hrvatske 1941.-1945. Zagreb, 2003.

3. Bjelajac, Mile. Generali i admirali Kraljevine Jugoslavije 1918-1941, Studija o vojnoj eliti i biografski leksikon. Beograd: INIS - Dobra, 2004.

4. Bjelajac, Mile. Jugoslovensko iskustvo sa multietničkom armijom 1918-1991. Beograd: UDI, 1999.

5. Bjelajac, M. "The Military and Yugoslav Unity". Yugoslavism. Histories of a Failed Idea 1918/1992, ed. Dejan Đokić, 208-221. London: Hurst and Co, 2003.

6. Bjelajac, Mile. Vojska Kraljevine SHS 1918-1921. Beograd: Narodna knjiga, 1988.

7. Bjelajac, Mile. Vojska Kraljevine SHS/Jugoslavije 1922-1935. Beograd: INIS, 1994.

8. Bjelajac, Mile, Gordana Krivokapić-Jović. Prilozi iz naučne kritike. Srpska istoriografija i svet. Beograd: INIS, 2011.

9. Čapo, Hrvoje. "Broj primljenih časnika bivše austrougarske vojske u vojsku Kraljevstva Srba, Hrvata I Slovenaca”. Časopis za suvremenu povijest, No 3/2008, (Zagreb), 1087-1103.

10. Ćorović, Vladimir. Crna knjiga: Patnje Srba Bosne i Hercegovine za vreme Svetskog rata 1914-1918. Beograd, 1920 (Beograd - Novi Sad, 2015). 
11. Deak, Istvan. Beyond Nationalism. A Social and Political History of the Habsburg Officer Corps 1848-1918. New York - Oxford: Oxford University Press, 1990.

12. Dedijer, Vladimir. Josip Broz Tito. Prilozi za biografiju. Beograd: Kultura, 1953.

13. Ekmečić, Milorad. Ogledi iz istorije. Beograd, 2002.

14. Ekmečić, M. Dugo kretanje između klanja i oranja. Istorija Srba u Novom veku (1492-1992). Beograd, 2007.

15. Fricke, Gert. Kroatien 1941-1945. Der "Unabhängige Staat" in der Sich des Deutschen Bevollmachtgten Generals in Agram Glaise v. Horstenau. Freiburg, 1972.

16. Furet, François. Le passé d’une illusion, Essai sur l'idée communiste en XXe siècle. Paris, 1995.

17. Gumz, Jonathan E. The Resurrection and Collapse of Empire in Habsburg Serbia, 1914-1918. Cambridge University Press, 2009.

18. Holzer, Anton. "Schüsse in Sabac, Die Massakeran der Zivilbevölkerung 1914". Der Grosse Krieg. Der Erste Weltkriegeim Spigel der serbischen Literatur und Presse, Gordana Ilic Markovic (Hg.). Wien: Promedia, 2014.

19. Holzer, Anton. Das Lächeln der Henker. Der unbekannte Krieg gegen die Zivibevölkerung 1914-1918. Darmstadt: Primus-Verlag, WBG, 2014 (In Serbian: Anton Holcer, Dželatov smešak. Nepoznati rat protiv civilnog stanovništva 1914-1918, Novi Sad - Beograd: Prometej-RTS, 2015).

20. Hory, L., Broszat, M. Der kroatischeUstascha-Staat 1941-1945. Stuttgart, 1964.

21. Kazimirović, Vasa. NDH u svetlu nemačkih dokumenata i dnevika Gleza fon Horstenaua 1941/1944. Beograd, 1987.

22. Knock, Thomas J. To End all Wars, Woodrow Wilson and the Quest for a New World Order. New York, 1992.

23. Košutić, Ivan. Hrvatsko domobranstvo u Drugom svjetskom ratu. Zagreb, 1992.

24. Kramer, Alan. Dynamic of Destruction. Culture and Mass Killing in the First World War. Oxford University Press, 2007.

25. Krizman, Bogdan. Raspad Austro-Ugarske i stvaranje jugoslovenske države. Zagreb: Školska knjiga, 1977.

26. Krizman, Bogdan. Hrvatska u Prvom svjetskom ratu, Hrvatsko-srpski politički odnosi. Zagreb: Globus, 1989.

27. Lopičić, dr Đorđe. Nemački ratni zločini 1941-1945. Presude jugoslovenskih vojnih sudova. Beograd, 2009.

28. Manoschek, Walter. "Serbienist Judenfrei", Militärische Besatzungspolitik und Judenvernichtung in Serbien 1941/42. München: R. Olde- 
nburg Verlag, 1993 (In Serbian: Holokaust u Srbiji. Vojna okupaciona politika i uništavanje Jevreja 1941-1942. Beograd, 2007.)

29. Mikić, Đorđe. Austrougarska ratna politika u Bosni i Hercegovini 1914-1918. Banja Luka, 2011.

30. Mitrovic, Andrej. Serbia's Great War 1914-1918. London: Hurst \& Co, 2007.

31. Mombauer, Annika. Helmut von Moltke and Origins of the First World War. Cambridge University Press, 2001 (2003, 2005).

32. Mosse, Georg L. Towards the Final Solution. A History of European Racism. New York, 1978 (In German translation: Die Geschichte des Rassismus in Europa; In Serbian: Mos Džordž L. Istorija rasizma u Evropi. Beograd: Službeni glasnik, 2005).

33. Namier, L. B. "History and Political Culture", The Varieties of History from Voltaire to the Present, ed. Fritz Stern, 371-386. New York, 1973.

34. Newman, John Paul. "The Croatian God Mars: The Impact of the war on the male wartime generation in Croatia". PhD thesis, Southampton University, 2008.

35. Paris, Edmond. Genocide in Satellite Croatia 1941-1945. A Record of Racial and Religious Persecutions and Massacres. Chicago, 1962.

36. Paschal, R. G., H. Haselsteiner, A. Suppan, Innere Front, Militärassistenz, Widerstand und Umsturz in der Donaumonarchie 1918. Wien, 1974.

37. Popović, Vladimir J. Patnje i žrtve Srba Sreza Trebinjskog. Trebinje, 1929 (reprint: Trebinje, 1996).

38. Reiss, Rudolf Archibald. Comment Les Austro-Hongrois ont fait la guerre en Serbie. Observations direct d'un neutre. Paris, 1915.

39. Ristović, Milan. Black Peter and Balkan Brigands. The Balkans and Serbia in German Satirical Journals 1903-1918. Beograd, 2003.

40. Ristović, Milan. Crni Petar i balkanski razbojnici, Balkan i Srbija u nemačkim satiričnim časopisima (1903-1918), Beograd, 2011.

41. Rothenburg, Gunther. The Army of Francis Joseph, West Lafayette. Indiana: Purdue University Press, 1998.

42. Shepherd, Ben. Terror in the Balkans / German Armies and Partisan Warfare. Cambridge, London: Harvard University Press, 2012.

43. Tienhoven, dr A. Van. Avec les Serbes en Serbie et en Albanie 19141916. Journal de Guerre d'un Chirurgien. Paris, 1918 (In Serbian: Sa Srbima u Srbiji i Albaniji 1914-1916. Ratni dnevnik jednog hirurga. Beograd - Novi Sad: Prometej-RTS, 2015).

44. Tko je tko u NDH, Hrvatska 1941.-1945. Zagreb: Minerva, 1997. 
45. Védrine, Hubert. Les Mondes de François Mitterand. Paris: Fayar, 1996.

46. Vlada Narodnog Vijeća SHS, Odio za narodnu obranu, Vjesnik naredaba 1918-1919. Zagreb: Hrvatski državni arhiv, 2008.

47. Young, Robert J. "Formation and Foreign Policy: Biography and EgoHistoire". French History Oxford Journals 24 (2), (2010, April), 144-163. 


\title{
Резиме
}

\author{
Миле Бјелајац
}

\section{Утицај Првог светског рата на начин размишљања и понашање официра у балканским збивањима: између два рата, у Другом светском рату и поратном периоду}

\begin{abstract}
Апстракт: Аутор у овом прегледном чланку указује на вишеслојно наслеђе Првог светског рата и његове последице на ментално здравље официра у међуратном периоду а нарочито током Другог светског рата на простору Балкана. Искуства аустроугарских официра на Источном и Јужном фронту 1914-1918. без икакве сумње су утицала на млађе и ниже официре на истом простору у ратном периоду од 1941. Поред ратних искустава и фрустрација, на ставове официра је утицала и пропаганда.
\end{abstract}

Кључне речи: ратни злочини, Балкан, Вермахт, аустроугарски официри, НДХ, Солунски фронт, Србија, Топлички устанак, Равногорски покрет

Обележавање 100 година од избијања Првог светског рата било је прилика да се изложе не само нова знања о његовим узроцима већ и многе контроверзе које су пратиле интерпретације. Сам рат, а још више последице које је он произвео исказују се као вишеслојне. Тотални рат, крај старог и почетак новог доба у Европи и Азији, нова улога САД-а, економска питања, епидемије заразних болести, утицај на мушко-женске односе, губици и многа друга питања обрађивана су на конференцијама и кроз литературу. Када је људски фактор у питању, посебно его-историја, уочене су трајне последице код многих учесника Великог рата. Већ је у стручним радовима примећено и анализирано да је код једне генерације која је активно учествовала у Другом светском рату на Балкану или Источном фронту један од доминантих фактора за деловање у новим условима било њихово специфично искуство из претходног рата. На Балкану и Источном фронту почињени су масовни ратни злочини у оба светска рата, посебно према незаштићеним цивилима и појединим социјалним групама. Установљено је да је у јединицама 
Вехрмахта после 1938. године било око 200 генерала и 600 пуковника бивших аустроугарских официра са претходним искуством на Балкану и на Источном фронту. Многи су после рата и суђени за почињене злочине. Овоме треба додати да је и у армијама Мађарске, Бугарске и Независне Државе Хрватске било много официра са сличним траумама и осећањима. Само у оружаним снагама ове последње било је 80 генерала и пуковника бивше монархије. Шовинизам и злочини из Првог светског рата само су настављени у новом рату. Појединима је после рата суђено пред војним и цивилним судовима. Поставило се неминовно питање: шта је утицало на те ставове? Показало се да су анимозитети и аустроугарска пропаганда против Србије и Срба на ширем простору били са дубљим коренима. У појединим периодима та пропаганда се поклапала са тајним припремама за прекрајање Србије. Пораз и слом Монархије у том сукобу додали су једну горчину и код неких жељу за осветом. У литератури је установљена и улога главнокомандујућих генерала и јединица војске у Србији у истребљивању Јевреја.

Разматрано је питање да ли је запостављеност некадашњих официра из Монархије у наследним земљама (Југославији, Румунији, Чехословачкој) допринела реваншистичком понашању на Балкану? Компаративном анализом је показано да су у Југославији слично пролазили и победнички српски (црногорски) официри и они из поражене армије међу којима је поред Хрвата било Срба и Словенаца. Па и међу генералима била су 64 бивша официра Аустро-угарске монархије. Југославија је много више него неке друге наследне земље отворила могућност промоције за ту категорију официра. После уједињења Италије, у првих 20 година само су Пијемонтези били на генералским положајима. Биће ипак да су неке друге околности, првенствено политичка и верска пропаганда утицале на стварање незадовољства.

На погледе и разумевање балканских прилика Први светски рат је оставио последице и код победничке стране. На првом месту то је геополитичко разумевање важности Балкана у будућем рату, а посебно солунске луке за снабдевање не само Југославије, Румуније него и Чехословачке и Пољске. Идеја о стварању нових експедиционих снага на Балкану те фабрика и база у Сирији директна је последица ратних искустава из 1916-1918. на западне планере. На другом месту, српска искуства гериле под окупацијом и Топличког устанка, посебно репресалија после његовог угушења, имала су последице на формирање доктрине Равногорског покрета пуковника, касније генерала Драгуљуба Михаиловића. 
Може да се закључи да су менталне последице Првог светског рата на његове активне учеснике, посебно генерације рођене 1880-1895, трајале у целом 20. веку. Искуства и ставови о томе како поступати према Србима или неким другим етничким групама, или како применом репресалија одговорити на устанак, директно су наслеђе Првог светског рата. 